\title{
Enhancement of Rotifer (Brachionus plicatilis) Growth by using Terrestrial Lactic Acid Bacteria
}

\author{
M. Planas*, J.A. Vázquez, J. Marqués, R. Pérez-Lomba, M. P. González, M. Murado \\ Instituto de Investigacions Mariñas (CSIC), C/ Eduardo Cabello, 6. 36208 Vigo, Spain
}

* Corresponding author: Tel.: +34-986-21 44 57; fax: +34-986-292762

E-mail address: mplanas@iim.csic.es (M. Planas)

\begin{abstract}
One of the pathways for the entry of bacteria, both pathogenic and probiotic, into the larvae of fish hatcheries is via live prey. As a preventive measure against infections, live prey may be cultured, supplementing the food with probiotics. Some lactic acid bacteria (LAB) have been successfully used in the larviculture. In this study, the nutritional effect of seven terrestrial LAB has been studied regarding the growth of the rotifer Brachionus plicatilis. The cultures were carried out without partial renewal of the culture medium, feeding the rotifers on baker's yeast and adding some of the species of bacteria. In all cases, the addition of the bacteria increased both the specific maximum growth rate and the maximum density obtainable in the cultures. However, the best results were obtained with the addition of Lactococcus lactis spp lactis, Pediococcus acidilactici or Lactobacillus casei ssp. casei. The rates of growth obtained with the individual or joint addition of these three bacteria were 8-13 times greater than those obtained with the control cultures after 4-5 days' culture. In this study, a series of kinetic models have been applied (logistic modified-Gompertz, logistic-logistic and generalised logistic) which describe the experimental data, obtaining a set of parameters of biological significance which facilitate the optimisation of the use of these bacterial strains in the mass production of rotifers.
\end{abstract}


Keywords: Brachionus plicatilis, rotifer, growth, lactic acid bacteria, factorial design.

\section{Introduction}

Bacteria colonise the intestines of the larvae from mouth opening (Hansen and Olafsen, 1999). The initial establishment of a microflora in the larval stages depends, among other factors, on the microbiota associated with eggs and newly hatched larvae, microalgae and live prey introduced into the system and water of the rearing system (Bolinches and Egidius, 1987; Hansen and Olafsen, 1989; Keskin et al., 1994).

Live prey (rotifer and Artemia) are important carriers of contamination of the larval digestive tract (Muroga et al., 1987; Nicolas et al., 1989; Cahill, 1999; Bergh et al., 1994; Blanch et al., 1997; Ringø and Birkbeck, 1999), which greatly determines the microbiota of the larvae and in many cases is responsible for significant mortality rates (Campbell and Buswell, 1983; Muroga et al., 1987; Grisez et al., 1997. In some studies, alternative methods (eggs disinfection, use of microbially-matured water or baths of prey in tap water) to antibiotics have been considered (Vadstein et al., 1993; Planas and Cunha, 1999; Skjermo and Vadstein, 1999) in order to reduce the microflora which accompanies the prey, but also the delivery of probiotic bacteria (Gatesoupe, 1991;; Gatesoupe, 1997; Harzevili et al., 1998; Gómez-Gil et al., 1998; Makridis et al., 2000; Gatesoupe, 2002).

The term probiotic has been defined by Verschuere et al. (2000) as a live microbial adjunct which has a beneficial effect on the host by modifying the host-associated or ambient microbial community, by insuring improved use of the feed or enhancing its nutritional value, by enhancing the host's response towards disease, or by improving the quality of its ambient environment. The positive effect of probiotics depends on both the action mechanisms and the capacity of colonisation, that is to say, its ability to reach, remain or reproduce in the place where the effect is required. 
The practice of larviculture implies discontinuous culture cycles which initially cause this situation not to be particularly suitable for the establishment of stable microbial communities. Instead of leaving the opportunity for spontaneous colonisation open, the culture systems may be colonised by a probiotic flora as a precaution. This colonisation may be carried out by supplying the probiotics directly to the rearing water (Strøm and Ringø, 1993; Ringo et al., 1996; Ringø and Vadstein, 1998) but also via live prey. Harmless bacteria have been effectively bioencapsulated in rotifers and Artemia generally by using short-time enrichments (Gatesoupe, 1997; Gómez-Gil et al., 1998; Makridis et al., 2000; Gatesoupe, 2002). Some of the strains can prevent the growth of bacterial pathogens (Gatesoupe, 1991; Verschuere et al., 2000: Villamil et al., 2003). However, information on the use of probiotics for continuous cultivation of rotifers is scarce. Two Lactobacillus-like strains increased the population density of rotifers (Gatesoupe, 1991). Similarly, Douillet $(2000 \mathrm{a}, \mathrm{b})$ reported enhancement of growth by using bacterial additives under synxenic and low density culture conditions. Hirata et al., (1998) proposed a recycled probiotic culture system for rotifers by incubating a mixture of some 40 species of bacteria.

The intensive culture of rotifers by using continuous or periodic additions of selected bacteria would enhance growth and modify the normal microbiota of rotifers. Terrestrial lactic acid bacteria (LAB) are great producers of bacteriocins and organic acids (lactic and acetic acids) which have inhibitory effects in vitro on the growth of some pathogens in fish (Vázquez, 2001). This study highlights the nutritional contribution of some terrestrial LAB in the intensive production of the rotifer Brachionus plicatilis. Some of the genera used in this study (Lactobacillus, Lactococcus, Pediococcus, Carnobacterium) have been previously used as probiotics in the larval rearing of marine fish (Verschuere et al., 2000). 


\section{Material and methods}

\subsection{Preparation of lactic acid bacteria}

Seven species of lactic acid bacteria (LAB) were used in this study (Table 1). Cultures were maintained as frozen stocks at $-50^{\circ} \mathrm{C}$ in powdered skimmed milk suspension containing $25 \%(\mathrm{v} / \mathrm{v})$ of glycerol (Cabo et al., 1999).

Batch cultures were carried out in a rotary agitator $(200 \mathrm{rpm})$ at $30^{\circ} \mathrm{C}$ in $250 \mathrm{ml}$ Erlenmeyer flasks with the optimum volumes $(75-200 \mathrm{ml}$, depending on the species) of MRS media (Man, Rogosa, Sharpe, Pronadisa S.A.) as reported by Vázquez, (2001). Inocula were prepared as cell suspensions in sterile distilled water and adjusted at $700 \mathrm{~nm}$ to an optical density of 0.800 . The inoculum size was always $1 \%(\mathrm{v} / \mathrm{v})$. Bacteria cultures were incubated for the time necessary for the micro-organisms to be in the transitional stage from exponential (order 1) to asymptotic (order 0) growth, bearing in mind the kinetics of logistical growth for these bacteria. (Vázquez, 2001). The criterion for obtaining biomass under reasonably standardised conditions was to use the culture time corresponding to biomass $X=0.8 \mathrm{~K}$ (the biomass at $80 \%$ of its asymptotic value). Thus, introducing this value into the logistical equation, we obtain:

$$
\begin{aligned}
& 0.8 K=\frac{K}{1+e^{c-r t_{0.8}}}, \text { and isolated } t_{0.8}: \\
& t_{0.8}=\frac{c+1,386}{r}, \text { where } c=\ln \left(\frac{K}{X_{0}}-1\right)
\end{aligned}
$$

At times pre-established by equation [1] for each bacteria, the bacterial biomass of each culture was harvested in the following way:

1: It was centrifuged at $5,000 \mathrm{rpm}$ for 15 minutes. The precipitate (probiotic biomass) was re-suspended in sterile water (salinity: $22 \mathrm{~g} \mathrm{l}^{-1}$ ). 
2: A second biomass wash was carried out under the same conditions as the first (centrifuging at 5,000 rpm for 15 minutes), eliminating all possible traces of postincubation medium.

3: It was suspended once again in seawater (salinity: $22 \mathrm{~g} \mathrm{l}^{-1}$, as for rotifer culture) and the spectrophotometry at a wavelength of $700 \mathrm{~nm}$ was measured. The optical density was converted to dry cell weight $\left(\mathrm{g} \mathrm{l}^{-1}\right)$ from a previously calculated standard curve.

\subsection{Rotifer culture}

The strain of rotifer used was Brachionus plicatilis O.F. Müller, provided by the company "Stolt Sea Farm S.A." (Spain), and originating from "SINTEF Centre of Aquaculture" (Norway). Rotifers were semi-continuously (partial water renewal) cultivated (200 rotifers $\left.\mathrm{ml}^{-1}\right)$ in cylindrical 160 -litre tanks at $23^{\circ} \mathrm{C}$ and a salinity of $22 \mathrm{~g} \mathrm{l}^{-}$ ${ }^{1}$. Rotifers were daily fed $\left(1.5 \mu \mathrm{g}_{\text {rotifer }}{ }^{-1}\right)$ on baker's yeast (Saccharomyces cerevisiae).

\subsection{Experimental protocols}

The rotifers were obtained from intensive production tanks, after filtration, washing and concentration in $53-\mu \mathrm{m}$ mesh, and transferred to a flask containing 2 litres of seawater at $22 \%$ salinity. The rotifers were subsequently inoculated into 1-litre flasks, containing $800 \mathrm{ml}$ of sterile seawater at $22 \%$ salinity. The inoculum was of 50 or 100 rotifers $\mathrm{ml}^{-1}$, with an initial percentage of ovigerous females of $15 \%-20 \%$. The flasks were arranged partially submerged in a controlled-temperature water bath $\left(23^{\circ} \mathrm{C}\right)$, were plugged with sterile cotton wool and were given gentle aeration by means of a porous diffuser in each. Feeding was carried out as indicated in the previous section.

\subsection{Experiment 1: The effect of different concentrations of Pediococcus acidilactici}

Immediately after the transfer of the rotifers to five 1-litre flasks (50 rotifers $\mathrm{ml}^{-1}$ ), different amounts of Pediococcus acidilactici $\left(0-0.436 \mathrm{mg} \mathrm{ml}^{-1}\right)$ were added, as shown 
in Table 2. The experiment was maintained for 8 days under the conditions described above, without renewing the water, and was repeated twice.

\subsection{Experiment 2: The effect of seven strains of lactic acid bacteria}

Seven flasks were inoculated with rotifers $\left(100\right.$ rotifers $\left.\mathrm{ml}^{-1}\right)$ and then with one of the seven species of LAB shown in Table 3. Another flask remained as control and was fed on baker's yeast. Rotifers were maintained for 7 days under the conditions described above, without renewing the water. The experiment was repeated twice.

\subsection{Experiment 3: Interactions between different lactic acid bacteria}

From the results of the previous experiments, a linear plan was designed which included the use of Pediococcus acidilactici Pc 1.02, Lactobacillus casei ssp. casei Lb 3.04 and Lactococcus lactis spp lactis Lc 1.04, chosen among all the available probiotic strains, due to their wide activity spectrum against other Gram-positive bacteria (Guerra and Pastrana, 2001).

The experimental plan was organized as a first-order complete factorial design (Box et al., 1989) with three variables (the three bacterial strains), each of them at three levels (concentrations), in such a way that the group defined three orthogonal vectors. Since covariance was this way eliminated, the empiric equation calculated from the results represents a description of the individual effects of the variables (coefficients of the firstorder terms) as well as their possible interactions (coefficients of the terms containing products of variables). Experimental domain (with quadruple replication in the center) and codification of the variables (into the interval $[-1 ; 1]$, as usual) are shown in Table 4. Bearing in mind that preliminary results suggested effects which were apparently more 
related to the logarithm of the dose than to its natural value, the natural values of the independent variables were chosen in logarithmic progression.

Equation was calculated from experimental data by means of the orthogonal least-squares method. Statistic significance of the coefficients were verified by means of Student t-test $(\alpha=0.05$ ), and model consistency (once non-significant coefficients removed) through Fisher $F$ test $(\alpha=0.05)$ applied to the following means squares ratios:

Model / Total error

(Model + Lack of fitting) / Model

Total error / Experimental error

Lack of fitting / Experimental error.

After inoculation of the rotifers $\left(50\right.$ rotifers $\left.\mathrm{ml}^{-1}\right)$, the different bacterial combinations were added and the cultures maintained for 7 days under the conditions described above, without renewing the culture medium.

\subsection{Kinetics of rotifer growth}

The data regarding rotifer density, expressed as a percentage in relation to the initial value, were adjusted to following lineal combinations of the well known logistic and Gompertz equations, modified to eliminate the intercept (Murado et al., 2002. See Appendix), a resort necessary to describe complex responses as those treated here:

1: Logistic modified - Gompertz:

$N=N_{i}\left[1+a e^{-b e^{-c t}}-K\left(\frac{1}{1+e^{r(m-t)}}-\frac{1}{1+e^{r m}}\right)\right]$

2: Logistic - logistic: 


$$
N=\frac{K}{1+e^{r(m-t)}}-\frac{K^{\prime}}{1+e^{r^{\prime}\left(m^{\prime}-t\right)}}
$$

The adjustments to models [2] and [3] were also compared to those corresponding to a generalised logistical equation (Edwards and Wilkie, 1968; Konak, 1975; La Motta, 1976; Knights, 1981), which includes a polynomial term in the exponential part:

$$
N=\frac{K}{1+e^{c-r\left(b_{0}+b_{1} t+b_{2} t^{2}+b_{3} t^{3}\right)}}
$$

\subsection{Statistics and numerical methods}

Fitting of models to experimental data was performed by means of the non-lineal leastsquares method (quasi-Newton), using the macro Solver included in the Excel 97 software package (Microsoft). A Student's t-test $(\alpha=0.05)$ was used to test the significance of coefficients. A Fisher Test $(\alpha=0.05)$ was used to test the consistency of models by using both the ratio between mean squares for error and mean squares for experimental error and the ratio between mean squares for experimental error and mean squares for lack of fitting. Models and tests were recalculated when non-significant coefficients were removed.

\section{Results}

In experiment 1 , the growth of the rotifer population in the presence of different concentrations of Pediococcus acidilactici Pc 1.02 was quantified (Table 2). In order to select the best model for the adjustment of the experimental data (Figure 1), the following aspects were taken into account: 
1: Economy of parameters (6 for model [3] compared with 7 for models [2] and [4]), likewise their physical significance (see symbolic notations table in Appendix).

2: The robustness of the model, in the sense (Murado et al., 2002) of minimising the effect of experimental error on the parameters of greatest practical interest (e.g. $r$ and $\left.r^{\prime}\right)$; this favours the logistical models.

3: The correlation between the expected values and those observed; this leads us to favour model [3] ( $r=0.9946)$ by a small margin, compared with model [4] ( $r=0.9942)$. By having direct physical significance, the most relevant data of the adjustment parameters (Table 2) are the times necessary in order to reach maximum population $\left(N_{\max }\right)$, and the specific maximum rates $r$ and $r$ ' (growth and decline of the curve, respectively). Although the kinetics of the control cultures (without Pc 1.02) conformed satisfactorily to equation [3], its tendencies differ considerably from those shown in the cultures treated with Pediococcus (Figure 1); for this reason we disregarded its adjustment parameters.

The results confirm that the presence of Pc 1.02 causes a considerable increase in the rotifer population at all concentrations tested. Taking into account the maximum population reachable (approximately 8 times control), the time within which the induction is achieved, the values of $r$ y $r^{\prime}$ (this is the only case where $r>r^{\prime}$ ) and the needs of lactic acid bacteria production, the most appropriate initial dose is estimated to be at a concentration of $0.09 \mathrm{~g} \mathrm{l}^{-1}$ of Pc 1.02 .

In experiment 2, the study was extended to the addition of $\mathrm{Ln} 3.07, \mathrm{Lb} 6.04, \mathrm{Cb} 1.01, \mathrm{Lc}$ 1.04, $\mathrm{Lb} 3.04$ and $\mathrm{Lb} 2.01$, applying the same criteria as in the previous experiment (Model [3]). Taking into account the relative bacteriocin activities in the extracts found by Murado et al., (2002), measured with $\mathrm{Cb} 1.01$ as the indicative species, the concentration of Lc 1.04 and Pc 1.02 used was $0.08 \mathrm{~g} \mathrm{l}^{-1}$, and double that in the rest. Once 
again, the growth rate results (Figure 2, Table 3) were favourable in all cases, all with $r<r^{\prime}$ (maximum specific growth rate lower than that of the decline). The highest growth rates were obtained with the addition of Lb 3.04 and Lc 1.04, which multiplied the initial concentration by three after 5.5 and 3 days' culture respectively, which, compared with the control, implies double the $N_{\max }$.

In experiment 3 the response was standardized referring the values of the rotifer populations to those obtained after 4 days (time that corresponds to the value of $N_{\max }$. Figure 3) in a control culture carried out, by duplicate, under the same conditions of the $3^{2}$ design, but without addition of bacteria (notice that this control is only a reference to standardize the results of the design, but it does not coincide with none of its points, every of which, included the central one, or zero, was treated with bacteria). This response can be described, using codified values for the independent variables (Table 4), by means of the following empirical equation (Table 5):

$$
Y=8.46+2.09 L b+1.09 L b L c+1.77 L b L c P c
$$

The results show that, into the experimental domain assayed, the maximum response was four times superior to the minimum one, which demonstrates the favourable effects of the bacterial strains used. Additionally, it is interesting to point out that, although only $L$. casei $(L b$ variable) promotes by itself stimulating effect $(\hat{Y}=11.24)$, the other two strains ( $L c$ and $P c$ variables) participate in interactions of positive sign, reason why the maximum response $(\hat{Y}=13.41)$ requires the simultaneous presence of all them to the highest concentrations (Table 5).

\section{Discussion}


One of the options generally used for kinetic comparison of cultures is using the specific growth rate $(\mu)$ and its corresponding linearisation [6].

$$
\mu=\frac{1}{N} \frac{d N}{d t} ; \text { and } \mu=\frac{1}{\left(t-t_{0}\right)}\left(\ln N-\ln N_{0}\right)
$$

Although this is the most widely used resource in bibliography, it does not allow the experimental data to be adjusted to a descriptive function and the subsequent obtaining of significant parameters.

Thus, in order to adjust the experimental profiles obtained from the experiments of this study, linear combinations of asymptotic equations (equations [2] to [4]) were used. This means is widely used in the world of physics, as is the case with the Heider-London equation (potential energy as a function of boundary ratio), which needs an exponential term (Born-Mayer) for the force of repulsion, and also a theoretical parabolic term for the force of attraction (Moore). A more detailed development of the models applied is shown in the Appendix, where the steps taken in the search for values of interest are described. The evolution of the experimental data obtained in this study was explained better by the Logistic+Logistic model (Model [3]).

Terrestrial LAB have a high capacity to produce bacteriocins (Guerra and Pastrana, 2001) and dominate the normal microbiota of the intestinal tract of endothermic animals. However, lactic acid bacteria are not usually found in fish even that they account for 5$10 \%$ of the total viable counts (Ringø and Gatesoupe, 1998). The main reasons for not isolated LAB from larvae are probably due to media, culture conditions or incubation time. Their presence in the larval state of fish is scarce, due to a series of limiting factors such as temperature or certain nutritional requirements. The effect of the addition of lactic acid bacteria in the larviculture of marine fish has been studied particularly with turbot (Gatesoupe, 1991; García de la Banda et al., 1992; Gatesoupe, 1994). In some 
cases it has been reported that the use of lactic acid bacteria modifies the microflora of larvae (Gatesoupe, 1994), improves rotifer growth (Harzevili et al., 1998; Gatesoupe, 1991), its nutritional value (Gatesoupe, 1991) and larval survival (García de la Banda et al., 1992), even when faced by infectious agents such as Vibrio (Gatesoupe, 1994).

The incorporation of these bacteria via live food constitutes a very important potential tool for supplying probionts to the larvae (Gatesoupe, 1991; García de la Banda et al., 1992; Gatesoupe, 1994).

For the use of probiotics on an industrial scale it is indispensable to establish optimal culture conditions for all the organisms which will appear in the food chain. In this study, given the diversity of terrestrial bacterial species, of varying qualities and effects, it was necessary to carry out a prior selection. We had at our disposal over 50 species of lactic acid bacteria, of which 7 species were selected a priori, due to their optimal antibacterial properties in vitro and because they were perfectly typified strains, their in-vitro properties being known in full detail (Guerra and Pastrana, 2001). Pediococcus acidilactici is one of the probiotics which present the greatest inhibitory activity (compared with $\mathrm{Cb}$ 1.01). In experiment 1, it was observed that an increase in the concentration of Pc 1.02 in the rotifer culture medium allows their growth to increase compared with a control without a probiotic, concluding that the optimal concentration was $0.09 \mathrm{mg} \mathrm{ml}^{-1}$. Growth in controls was negative in this experiment probably due to a low physiological status of the rotifers at the moment of the inoculation. However, condition of rotifers improved notoriously with the addition of LAB.

Based on the results obtained in experiment 1, the effect of 7 other species of lactic acid bacteria was studied (experiment 2), which allowed us to select three species (experiment 3), Pc 1.02, Lc 1.04 and Lb 3.04, with which positive results were obtained in terms of rotifer growth and to see possible synergic effects between them. The first two are 
producers of pediocin and nisin, respectively, while Lb 3.04 is a very typified lactic acid bacteria, but very distant in the similarity dendogram of these bacteria (Guerra and Pastrana, 2001).

Lactobacillus casei spp casei showed itself to be the most suitable terrestrial lactic acid bacteria for rotifer growth. The use of other species of the genus Lactobacillus in live prey has already been disclosed by other authors. Higher rotifer growth rates have been reported using L. plantarum and L. helveticus (Gatesoupe, 1991) and also important changes in the microbiota with the addition of Lactobacillus/Carnobacterium (Gatesoupe, 1994). A reduction in the level of Vibrio alginolyticus in Artemia nauplii, kept for 24 hours in the presence of L. brevis has also been described (Villamil et al., 2003). Gatesoupe, (1991) observed the inhibition of Aeromonas salmonicida with the addition of L. plantarum. Likewise, Pérez-Lomba (2001) described a considerable increase in the growth rate of Isochrysis galbana with the delivery of L. helveticus Carnobacterium piscicola, or Leuconostoc mesenteroides spp mesenteroides.

The use of probiotics has advantages both at an environmental level, as antibioticresistant micro-organisms are not being produced, and at an economic level, as their production costs are lower than other treatments if the conditions and the culture media are optimised. According to the results obtained in experiment 3, a simple resource to

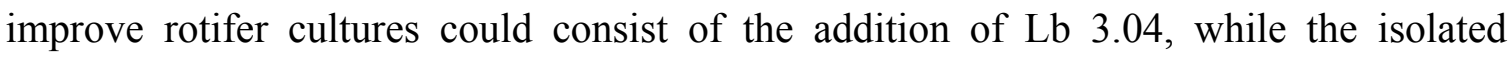
addition of the other probionts, likewise their binary combination, or that of any of them with Lb 3.04, would have no practical use. From the coefficients of the equation obtained we can infer the effect that the different combinations of LAB have on the development of the rotifer. It must be borne in mind that the independent term (which is related to the influence of the medium) has a very high value (8.46), in relation to the rest of the coefficients, which shows us that there are many factors which we cannot control and 
which greatly influence our system, and therefore the equation obtained (ammonia, oxygen, turbulence, etc).

It must be emphasised that all the experiments were carried out without renewing the water. As one of the causes of the population drop in rotifer populations in culture systems is the accumulation of ammonia (Yu and Hirayama, 1986) and, to a lesser extent, of nitrites (Lubzens, 1987), it seems reasonable to suppose that the maximum densities obtained in this study could have been higher in the event of carrying out partial renewals of the medium. To this effect, the lower rotifer growth achieved in experiment 2 may well be due to the higher initial population of rotifers $\left(100 \operatorname{rot~ml}^{-1} ; 50 \operatorname{rot~ml}^{-1}\right.$ in experiments 1 and 3), which causes the critical concentration to be reached more quickly. This concentration is estimated to be 200-400 rot $\mathrm{ml}^{-1}$ in cultures without partial water renewal.

The increase in rotifer population growth in the presence of the bacteria used may be due to a number of reasons. The success of mass cultures in rotifers may be improved by the products of decomposition (Tanaka, 1991), or by the growth of bacteria in the culture tanks (Hirayama, 1987). One of the possible causes may be the production of vitamin $B_{12}$ by the bacteria present in the culture medium (Hirayama and Funamoto, 1983; Yu et al., 1989). This vitamin is essential to B. plicatilis (Scott, 1981). On the other hand, the supplementation of lactic acid bacteria not only increases the rate of production of the rotifers but also has a regulating effect on the microflora. Gatesoupe, (1991) reported that feeding the rotifers with Lactobacillus plantarum is an effective way to decrease the bacterial counts, especially the counts of the dominant Vibrionacea in rotifers. Rombaut et al., (1999) and Douillet, (2000a,b) were able to find five bacterial strains that were able to improve the reproduction of axenic rotifers cultured under monoxenic or synxenic culture conditions. 
Some authors reported no increase in the growth rate of the rotifers under optimal culture conditions after addition of Lactococcus lactis AR21 to the diet (Harzevili et al., 1998). However, in the present paper, rotifers were fed on baker's yeast in excess and the increase in rotifer production with the addition of LAB was clear. Furthermore, the enhancement of the rotifer growth rate by adding mixtures of bacteria strains was also reported by Douillet, (2000b) and Gatesoupe, (1991). Our results show that a blend of 3 strains of LAB produces the highest growth in rotifer population, although the main effect is due to only one of them: Lactobacillus casei spp casei (Lb 3.04) .

The lactic acid bacteria used in this study are of terrestrial origin, therefore it is important to bear in mind their survival rate in salt water and thus maintain a relatively constant concentration during time. Pérez-Lomba, (2001) showed that the initial level of the LAB used in this study remains relatively stable in seawater during the first 2-4 days, depending on the species. From that moment on it drops in exponential terms. It is possible that the periodic addition of bacteria, after initiation of the culture, may improve the results obtained.

\section{Acknowledgements}

This study was funded by the Projects Production and Application of Probiotics in the Improvement of Larval Survival in Larval Cultures of Sea Fish (1FD97-0044-C03-01/02) from CICYT - FEDER and Improved procedures for flatfish larval rearing through the use of probiotic bacteria (PROBE) from European Commission (contract no. Q5RS2000-31457). Dr. J.A. Vázquez wishes to thank CSIC - Diputación Provincial de Pontevedra for a research grant. Pediococcus acidilactici was kindly donated by the Northern Regional research Laboratory (Peoria, Illinois, USA). We are grateful to Alicia Abalo for technical assistance. 


\section{Appendix}

\section{Equation 'logistic-logistic':}

$$
N=\frac{K}{1+e^{r(m-t)}}-\frac{K^{\prime}}{1+e^{r^{\prime}\left(m^{\prime}-t\right)}}
$$

Determination of $N_{0}$ and $N_{\infty}$ :

$$
\begin{aligned}
& N_{0}=\lim _{t \rightarrow 0} \frac{K}{1+e^{r m}}-\frac{K^{\prime}}{1+e^{r^{\prime} m^{\prime}}}, \forall r, m, r^{\prime}, m^{\prime} \\
& N_{\infty}=\lim _{t \rightarrow \infty} \frac{K}{1+e^{r(m-\infty)}}-\frac{K^{\prime}}{1+e^{r^{\prime}\left(m^{\prime}-\infty\right)}}=\frac{K}{1+e^{-\infty}}-\frac{K^{\prime}}{1+e^{-\infty}}=K-K^{\prime}, \\
& \forall r, m, r^{\prime}, m^{\prime}>0
\end{aligned}
$$

In order to obtain the maximum, we proceed in the following way:

$$
\begin{aligned}
& \frac{d N}{d t}=\frac{K r e^{r(m-t)}}{\left(1+e^{r(m-t)}\right)^{2}}-\frac{K^{\prime} r^{\prime} e^{r^{\prime}\left(m^{\prime}-t\right)}}{\left(1+e^{r^{\prime}\left(m^{\prime}-t\right)}\right)^{2}}=0 \\
& \frac{K r e^{r(m-t)}}{\left(1+e^{r(m-t)}\right)^{2}}=\frac{K^{\prime} r^{\prime} e^{r^{\prime}\left(m^{\prime}-t\right)}}{\left(1+e^{r^{\prime}\left(m^{\prime}-t\right)}\right)^{2}}
\end{aligned}
$$

which once again produces an important equation, which allows four possible ways of finding $t$ and of calculating it by means of numerical iteration until $t_{i}=t_{i-1}$.
i) $t_{i}=m-\frac{1}{r} \ln \left(\frac{K^{\prime} r^{\prime} e^{r^{\prime}\left(m^{\prime}-t_{i-1}\right)}\left(1+e^{r\left(m-t_{i-1}\right)}\right)^{2}}{K r\left(1+e^{r^{\prime}\left(m^{\prime}-t_{i-1}\right)}\right)^{2}}\right)$
ii) $t_{i}=m^{\prime}-\frac{1}{r^{\prime}} \ln \left(\frac{K r e^{r\left(m-t_{i-1}\right)}\left(1+e^{r^{\prime}\left(m^{\prime}-t_{i-1}\right)}\right)^{2}}{K^{\prime} r^{\prime}\left(1+e^{r\left(m-t_{i-1}\right)}\right)^{2}}\right)$
iii) $t_{i}=m-\frac{1}{r} \ln \left[\sqrt{\frac{K r e^{r\left(m-t_{i-1}\right)}\left(1+e^{r^{\prime}\left(m^{\prime}-t_{i-1}\right)}\right)^{2}}{K^{\prime} r^{\prime} e^{r^{\prime}\left(m^{\prime}-t_{i-1}\right)}}}-1\right]$ 
iv) $t_{i}=m^{\prime}-\frac{1}{r^{\prime}} \ln \left[\sqrt{\frac{K^{\prime} r^{\prime} e^{r^{\prime}\left(m^{\prime}-t_{i-1}\right)}\left(1+e^{r\left(m-t_{i-1}\right)}\right)^{2}}{K r e^{r\left(m-t_{i-1}\right)}}}-1\right]$

where experimental reality advises method iv). Making $t_{i}=t_{\max }$ and exchanging this value

$t_{\max }$ for $N(t)$, we obtain $N_{\max }$, finding that:

$$
\begin{aligned}
& \text { for } t<t_{\text {max }} \rightarrow \frac{d N}{d t}=f^{\prime}(N, t)>0, \text { the function is increased } \\
& \text { for } t>t_{\max } \rightarrow \frac{d N}{d t}=f^{\prime}(N, t)<0, \text { the function is decreased }
\end{aligned}
$$

and, used to the second derivate:

\begin{tabular}{|c|c|c|}
\hline \multicolumn{3}{|l|}{ Symbolic notations used } \\
\hline \multirow{2}{*}{$\begin{array}{l}\text { EQUATION } \\
\text { Logistic modified-Gompertz }\end{array}$} & \multicolumn{2}{|c|}{ PARAMETER } \\
\hline & $\begin{array}{l}N, t: \\
N_{i}: \\
K: \\
r: \\
m: \\
a, b: \\
c:\end{array}$ & $\begin{array}{l}\text { amount of rotifers (\% of initial population) and time, respectively. } \\
\text { parameter to be empirically determined. Dimensions } N \text {. } \\
\text { parameter to be empirically determined. Dimensionless. } \\
\text { specific maximum growth rate. Dimensions } t^{-1} \text {. } \\
\text { parameter to be empirically determined. Dimensions } t \text {. } \\
\text { parameter to be empirically determined. Dimensionless. } \\
\text { specific response tax. Dimensions } t^{-1} \text {. }\end{array}$ \\
\hline Logistic-logistic & $\begin{array}{l}N, t: \\
K, K^{\prime}: \\
r, r^{\prime}: \\
m, m^{\prime}:\end{array}$ & $\begin{array}{l}\text { amount of rotifers (\% of initial population) and time, respectively. } \\
\text { parameter to be empirically determined. Dimensions } N \text {. } \\
\text { specific maximum growth rate on the two lengths. Dimensions } t^{-1} \text {. } \\
\text { parameter to be empirically determined. Dimensions } t \text {. }\end{array}$ \\
\hline Generalised logistic & $\begin{array}{l}N, t: \\
K: \\
r, b_{o} \\
b_{1}: \\
b_{2}: \\
b_{3}:\end{array}$ & $\begin{array}{l}\text { amount of rotifers (\% of initial population) and time, respectively } \\
\text { maximum response. Dimensions } N \text {. } \\
\text { parameter to be empirically determined. Dimensionless. } \\
\text { parameter to be empirically determined. Dimensions } t^{-1} \text {. } \\
\text { parameter to be empirically determined. Dimensions } t^{-2} \text {. } \\
\text { parameter to be empirically determined. Dimensions } t^{-3} \text {. }\end{array}$ \\
\hline
\end{tabular}

$$
t_{\max } \rightarrow \frac{d^{2} N}{d t^{2}}=f^{\prime \prime}(N, t)<0, \text { for this reason } t_{\max } \text { is definitively a maximum. }
$$




\section{References}

Bergh, Ø., Naas, K.E., Harboe, T., 1994. Shift in the intestinal microflora of Atlantic halibut (Hippoglossus hippoglossus) larvae during first feeding. Can. J. Fish. Aquat. Sci. 51, 1899-1903.

Blanch, A.R., Alsina, M., Simon, M., Jofre, J., 1997. Determination of bacteria associated with reared turbot (Scophthalmus maximus) larvae. J. Appl. Microbiol. 82, 729-734.

Bolinches, J., Egidius, E., 1987. Heterotrophic bacterial communities associated with the larval rearing of halibut Hippoglossus hippoglossus with special reference to Vibrio spp. J. Appl. Ichthyol. 3, 165-173.

Box, G.E.P., Hunter, W.G., Hunter, J.S., 1989. «Estadística para investigadores». Reverté, Barcelona, 700 pp.

Cabo, M.L., Murado, M.A., González, M.P., Pastoriza, L., 1999. A method for bacteriocin quantification. J. Appl. Microbiol. 87, 907-914.

Cahill, M.M., 1990. Bacterial flora of fishes: A review. Microb.Ecol. 19, 21-41.

Campbell, A.C., Buswell, J.A., 1983. The intestinal microflora of farmed Dover sole (Solea solea) at different stages of fish development. J. Appl. Bacteriol. 55, 215-223.

Douillet, P.A., 2000a. Bacterial additives that consistently enhance rotifer growth under synxenic culture conditions. 1. Evaluation of commercial products and pure isolates. Aquaculture 182, 249-260.

Douillet, P.A., 2000b. Bacterial additives that consistently enhance rotifer growth under synxenic culture conditions. 2. Use of single and multiple bacterial probiotics. Aquaculture 182, 241-248. 
Edwards, V.H., Wilkie, C.R., 1968. Mathematical representation of batch culture data. Biotechnolog. Bioeng. 10, 205-232.

García de la Banda, I., Chereguini, O., Rasines, I., 1992. Improvement of turbot larvae development by lactic bacterial addition. ICES C.M., 92/F:8, 8p.

Gatesoupe, F.-J., 1991. The effect of three strains of lactic bacteria on the production rate of rotifers, Brachionus plicatilis, and their dietary value for larval turbot, Scophthalmus maximus. Aquaculture 96, 335-342.

Gatesoupe, F.-J., 1994. Lactic acid bacteria increase the resistance of turbot larvae, Scophthalmus maximus, against pathogenic vibrio. Aquat. Living Resour. 7, 277-282.

Gatesoupe, F.-J., 1997. Siderophore production and probiotic effect of Vibrio sp. associated with turbot larvae, Scophthalmus maximus. Aquat. Living Resour.10, 239246.

Gatesoupe, F.J., 2002. Probiotic and formaldehyde treatment of Artemia nauplii as food for larval pollack, Pollachius pollachius. Aquaculture 212, 347-360.

Gómez-Gil, B., Herrera-Vega, M.A., Abreu-Grobois, F.A., Roque, A., 1998. Bioencapsulation of two different Vibrio species in nauplii of the brine shrimp (Artemia franciscana). Appl. Envir. Microbiol. 64, 2318-2322.

Grisez, L., Reyniers, J., Verdonck, L., Swings, J., Ollevier, F., 1997. Dominant intestinal microflora of sea bream and sea bass larvae, from two hatcheries, during larval development. Aquaculture 155, 377-399.

Guerra, N.P., Pastrana, L., 2001. Modelling the influence of $\mathrm{pH}$ on the kinetics of both nisin and pediocin production and characterization of their functional properties. Proc. Biochem. 37, 1005-1015. 
Hansen, G.H., Olafsen, J.A., 1989. Bacterial colonization of cod (Gadus morhua) and halibut (Hippoglossus hippoglossus) eggs in marine aquaculture. Appl. Envir. Microbiol. 55, 1435-1446.

Hansen, G.H., Olafsen, J.A., 1999. Bacterial interactions in early life stages of marine cold water fish. Microbiol. Ecol. 38, 1-26.

Harzevili, A.R.S., Van Duffel, H., Dhert, P., Swings, J., Sorgeloos, P., 1998. Use of a potential probiotic Lactococcus lactis AR21 strain for the enhancement of growth in the rotifer Brachionus plicatilis (Müller). Aquacult. Res. 29, 411-417.

Hirata, H., Murata, O., Yamada, S., Ishitami, H., Wachi, M., 1998. Probiotic culture of the rotifer Brachionus plicatilis. Hydrobiologia 387/388, 495-498.

Hirayama, K., 1987. A consideration of why mass culture of the rotifer Brachionus plicatilis with baker's yeast is unstable. Hydrobiologia 147, 269-270.

Hirayama, K., Funamoto, H., 1983. Supplementary effect of several nutrients on nutritive deficiency of baker's yeast for population growth of the rotifer Brachionus plicatilis. Bull. Jap. Soc. Sci. Fish 49, 505-510.

Keskin, M., Keskin, M., Rosenthal, H., 1994. Pathways of bacterial contamination during egg incubation and larval rearing of turbot, Scophthalmus maximus. J. Appl. Ichthyol. $10,1-9$.

Knights, A.J., 1981. Determination of the biological kinetic parameters of fermenter design from batch culture data. Ph.D. Thesis, University of Wales (Wales).

Konak, A.R., 1975. An equation for batch bacterial growth. Biotechnol. Bioeng. 17, 271280. 
La Motta, E.J., 1976. Kinetics of continuous growth culture using the logistic growth curve. Biotechnol. Bioeng. 187, 1029-1036.

Lubzens, E., 1987. Raising rotifers for use in aquaculture. Hydrobiologia 147, 245-255.

Makridis, P., Fjellheim, A.J., Skjermo, J., Vadstein, O., 2000. Control of bacterial flora of Brachionus plicatilis and Artemia franciscana by incubation in bacterial suspension. Aquaculture 185, 207-218.

Murado, M.A., González, MP., and Vázquez, J.A., 2002. Dose-response relationships. An overview, a generative model and its application to the verification of descriptive models. Enzyme Microb. Technol. 6097, 1-17.

Muroga, K., Higashi, M., and Keitoku, H., 1987. The isolation of intestinal microflora of farmed red seabream (Pagrus major) and black seabream (Acanthopagrus schlegeli) at larval and juvenile stages. Aquaculture 65, 79-88.

Nicolas, J.L., Robic, E. and Ansquer, D., 1989. Bacterial flora associated with a trophic chain consisting of microalgae, rotifers and turbot larvae: Influence of bacteria on larval survival. Aquaculture 83, 237-248.

Pérez-Lomba, R.M., 2001. Aplicación de bacterias lácticas nos sistemas de cultivo larvario de peixes. Tese de Licenciatura. University of Vigo (Spain), 74 p.

Planas, M., Cunha, I., 1999. Larviculture of marine fish: Problems and perspectives. Aquaculture, 177, 171-190.

Ringø, E., Birkbeck, T.H., Munro, P.D., Vadstein, O., Hjelmeland, K., 1996. The effect of early exposure to Vibrio pelagius on the aerobic bacterial flora of turbot Scophthalmus maximus (L.) larvae. J. Appl. Bacteriol. 81, 207-211. 
Ringø, E., Gatesoupe, F.-J., 1998. Lactic acid bacteria in fish: a review. Aquaculture 160, 177-203.

Ringø, E., Vadstein, O., 1998. Colonization of Vibrio pelagius and Aeromonas caviae in early developing turbot Scophthalmus maximus (L.) larvae. J. Appl. Microbiol. 84, $227-233$.

Ringø, E., Birkbeck, T.H., 1999. Intestinal microflora of fish larvae and fry.. Aquacult. Res. 30, 73-93.

Rombaut, G., Dhert, Ph., Vandenbergue, J., Verschuere, L., Sorgeloos, P., Verstraete, W., 1999. Selection of bacteria enhancing the growth rate of axenically hatched rotifers (Brachionus plicatilis). Aquaculture 176, 195-207.

Scott, J.M., 1981. The vitamin $\mathrm{B}_{12}$ requirement of the marine rotifer Brachionus plicatilis. J. Mar. Biol. Assoc. UK 61, 983-994.

Skjermo, J., Vadstein, O., 1999. Techniques for microbial control in the intensive rearing of marine larvae. Aquaculture 177, 333-343.

Strøm, E., Ringø, E., 1993. Changes in the bacterial composition of early developing cod, Gadus morhua L., larvae following inoculation of Lactobacillus plantarum into the water. In: Walther, B., Fyhn, H.J. (Eeds.), Physiological and Biochemical Aspects of Fish Larval Development, Grafisk Hus, Bergen, 226-228.

Tanaka, Y., 1991. Nitrogen budget for the rotifer Brachionus plicatilis. J. World Aquacult. Soc. 22, 57-64.

Vadstein, O., Øie, G., Salvesen, I., Skjermo, J., Skjak-Braek, G., 1993. A strategy to obtain microbial control during larval development of marine fish. In: Reinertsen, $\mathrm{H}$. Dahle, L.A., Jørgensen, L., Tvinnereim K. (Eds,), Proceedings of the First 
International Conference on Fish Farming Technology, A.A.Balkema, Rotterdam, 6975.

Vázquez, J.A., 2001. Lactobacterias como probiontes e produtoras de bacteriocinas. Modelos de crecemento e actividade. Aplicacións á acuicultura. Ph.D. Thesis University of Santiago de Compostela (Spain), 346 p.

Verschuere, L., Heang, H., Criel, G.R., Sorgeloos, P., Verestrate, W., 2000. Selected bacterial strains protect Artemia spp. from the pathogenic effects of Vibrio proteoliticus CW8T2. Appl. Environ. Microbiol. 66, 1139-1146.

Villamil, L., Figueras, A., Planas, M., Novoa, B., 2003. Control of Vibrio alginolyticus in Artemia culture by treatment with bacterial probiotics. Aquaculture 219, 43-56.

Yu, J.P., Hirayama, K., 1986. The effect of un-ionized ammonia on the population growth of the rotifer in mass culture. Bull. Jpn. Soc. Sci. Fish. 52, 1509-1513.

Yu, J.P., Hino, A., Ushiro, M.,Maeda, M., 1989. Function of bacteria as vitamin B12producers during mass cultura of the rotifer Brachionus plicatilis. Nippon Suisan Gakkaishi 55:1799-1806. 
Table 1: Lactic acid bacteria strains tested with rotifers.

\begin{tabular}{llll}
\hline \multicolumn{1}{c}{ Species } & Key & & Origin \\
\hline Carnobacterium piscicola & Cb 1.01 & CECT 4020 & Cultivated trout \\
Lactobacillus brevis & Lb 2.01 & CECT 216 & Beer \\
Lactobacillus casei ssp. casei & Lb 3.04 & CECT 4043 & Majorero cheese \\
Lactobacillus helveticus $_{\text {Lactococcus lactis spp lactis }}^{\text {Lb 6.04 }}$ & CECT 541 & Gruyere cheese \\
Leuconostoc mesenteroides spp mesenteroides $^{\text {Pediococcus acidilactici* }}$ & LC 1.04 & CECT 539 & Milk \\
Ped.07 & CECT 4046 & Pressed curt \\
\hline
\end{tabular}

CECT: Spanish Type Culture Collection

NRRL: Nothern Regional Research Laboratory (Peoria, Illinois, USA)

Key: nomenclature used in this study. 
Table 2: Experiment 1- Concentrations of Pediococcus acidilactici (mg ml-1; CFU ml-1) and main parameters ( $N_{\max }, t_{\max }, r$ and $\left.r^{\prime}\right)$ of rotifer growth (Model [3]).

\begin{tabular}{cccccc}
\hline Flask & $\mathrm{mg} / \mathrm{ml}\left(\mathrm{CFU} \mathrm{m} \mathrm{l}^{-1}\right)$ & $N_{\max }(\%)$ & $t_{\max }($ days $)$ & $r$ (days $\left.^{-1}\right)$ & $r^{\prime}$ (days $\left.^{-1}\right)$ \\
\hline Control & - & - & - & - & - \\
1 & $0.022\left(3.1 \times 10^{8}\right)$ & 147 & 2.58 & 0.640 & 3.216 \\
2 & $0.088\left(1.3 \times 10^{9}\right)$ & 274 & 6.74 & 0.209 & 0.103 \\
3 & $0.216\left(3.1 \times 10^{9}\right)$ & 331 & 6.51 & 0.753 & 12.283 \\
4 & $0.436\left(6.1 \times 10^{9}\right)$ & 382 & 5.72 & 0.557 & 0.644 \\
\hline
\end{tabular}


Table 3: Experiment 2 - Concentrations (mg ml-1; CFU ml-1) of different lactic acid bacteria and main parameters ( $N_{\max }, t_{\max }, r$ and $\left.r^{\prime}\right)$ of rotifer growth (Model [3]).

\begin{tabular}{|c|c|c|c|c|c|}
\hline Strain & $\mathrm{mg} / \mathrm{ml}\left(\mathrm{CFU} \mathrm{ml}^{-1}\right)$ & $N_{\max }(\%)$ & $t_{\max }$ (days) & $r\left(\right.$ days $\left.^{-1}\right)$ & $r^{\prime}\left(\right.$ days $\left.^{-1}\right)$ \\
\hline Control & & 147 & 3.48 & 0.934 & 1.963 \\
\hline Cb 1.01 & $0.20\left(3.0 \times 10^{9}\right)$ & 193 & 2.91 & 1.027 & 2.217 \\
\hline Lb 2.01 & $0.20\left(1.4 \times 10^{9}\right)$ & 214 & 2.46 & 0.849 & 0.879 \\
\hline Lb 3.04 & $0.20\left(6.3 \times 10^{9}\right)$ & 323 & 5.55 & 0.479 & 1.652 \\
\hline Lb 6.04 & $0.20\left(9.0 \times 10^{9}\right)$ & 223 & 3.04 & 0.988 & 2.474 \\
\hline LC 1.04 & $0.08\left(1.1 \times 10^{9}\right)$ & 280 & 2.99 & 1.055 & 2.139 \\
\hline $\operatorname{Ln} 3.07$ & $0.20\left(4.5 \times 10^{9}\right)$ & 239 & 3.06 & 0.630 & 0.988 \\
\hline Pc 1.02 & $0.08\left(1.2 \times 10^{9}\right)$ & 165 & 2.80 & 0.463 & 1.100 \\
\hline
\end{tabular}


Table 4: Concentrations (mg ml-1; CFU ml-1) of Lb 3.04, Lc 1.04 and Pc 1.02 in experiment 3 and codified values for each variable.

\begin{tabular}{|c|c|c|c|c|c|c|}
\hline \multirow[t]{2}{*}{ Flask } & \multirow{2}{*}{\multicolumn{3}{|c|}{$\begin{array}{l}\text { Codified } \\
\text { Values }\end{array}$}} & \multicolumn{3}{|c|}{ Natural Values: $\mathrm{mg} \mathrm{ml}^{-1}\left(\mathrm{CFU} \mathrm{ml}^{-1}\right)$} \\
\hline & & & & Lb 3.04 & Lc 1.04 & Pc 1.02 \\
\hline 1 & -1 & -1 & -1 & $0.050\left(1.3 \times 10^{9}\right)$ & $0.020\left(2.9 \times 10^{8}\right)$ & $0.021\left(3.0 \times 10^{8}\right)$ \\
\hline 2 & 1 & -1 & -1 & $0.400\left(1.1 \times 10^{10}\right)$ & $0.020\left(2.9 \times 10^{8}\right)$ & $0.021\left(3.0 \times 10^{8}\right)$ \\
\hline 3 & -1 & 1 & -1 & $0.050\left(1.3 \times 10^{9}\right)$ & $0.159\left(2.3 \times 10^{9}\right)$ & $0.021\left(3.0 \times 10^{8}\right)$ \\
\hline 4 & 1 & 1 & -1 & $0.400\left(1.1 \times 10^{10}\right)$ & $0.159\left(2.3 \times 10^{9}\right)$ & $0.021\left(3.0 \times 10^{8}\right)$ \\
\hline 5 & -1 & -1 & 1 & $0.050\left(1.3 \times 10^{9}\right)$ & $0.020\left(2.9 \times 10^{8}\right)$ & $0.165\left(2.3 \times 10^{9}\right)$ \\
\hline 6 & 1 & -1 & 1 & $0.400\left(1.1 \times 10^{10}\right)$ & $0.020\left(2.9 \times 10^{8}\right)$ & $0.165\left(2.3 \times 10^{9}\right)$ \\
\hline 7 & -1 & 1 & 1 & $0.050(1.3 \times 109)$ & $0.159\left(2.3 \times 10^{9}\right)$ & $0.165\left(2.3 \times 10^{9}\right)$ \\
\hline 8 & 1 & 1 & 1 & $0.400\left(1.1 \times 10^{10}\right)$ & $0.159\left(2.3 \times 10^{9}\right)$ & $0.165\left(2.3 \times 10^{9}\right)$ \\
\hline 9 & 0 & 0 & 0 & $0.137\left(3.8 \times 10^{9}\right)$ & $0.055\left(7.8 \times 10^{8}\right)$ & $0.057\left(8.0 \times 10^{8}\right)$ \\
\hline 10 & 0 & 0 & 0 & $0.137\left(3.8 \times 10^{9}\right)$ & $0.055\left(7.8 \times 10^{8}\right)$ & $0.057\left(8.0 \times 10^{8}\right)$ \\
\hline 11 & 0 & 0 & 0 & $0.137\left(3.8 \times 10^{9}\right)$ & $0.055\left(7.8 \times 10^{8}\right)$ & $0.057\left(8.0 \times 10^{8}\right)$ \\
\hline 12 & 0 & 0 & 0 & $0.137\left(3.8 \times 10^{9}\right)$ & $0.055\left(7.8 \times 10^{8}\right)$ & $0.057\left(8.0 \times 10^{8}\right)$ \\
\hline
\end{tabular}


Table 5. Results of factorial design and tests of significance for model (5). $Y$ : normalised rotifer values regarding the untreated control $\hat{Y}$ : normalised rotifer values regarding the untreated control estimates from eqn (5); NS: not significative coefficient; SS: sum of squares; $v$ : degrees of freedom; MS: mean squares; MSM: mean squares model; MSE: mean squares for error; MSMLF: mean squares model for lack of fit; MSEe: mean squares for experimental error.

\begin{tabular}{|c|c|c|c|c|c|c|c|}
\hline Lb 3.04 & LC 1.04 & Pc 1.02 & $Y$ & $\hat{Y}$ & Coefficients & $\mathrm{t}$ & Model \\
\hline-1 & -1 & -1 & 5.19 & 5.69 & 8.46 & 31.8 & 8.46 \\
\hline 1 & -1 & -1 & 9.88 & 11.24 & 2.09 & 6.4 & $2.09 \mathrm{Lb}$ \\
\hline-1 & 1 & -1 & 7.00 & 7.07 & -0.02 & 0.1 & NS LC \\
\hline 1 & 1 & -1 & 8.94 & 9.86 & 0.23 & 0.7 & NS Pc \\
\hline-1 & -1 & 1 & 8.81 & 9.24 & 1.09 & 3.3 & 1.09 LbLc \\
\hline 1 & -1 & 1 & 8.13 & 7.69 & 0.43 & 1.3 & NS LbPc \\
\hline-1 & 1 & 1 & 2.56 & 3.52 & -0.24 & 0.7 & NS LCPc \\
\hline 1 & 1 & 1 & 13.31 & 13.41 & 1.77 & 5.4 & 1.77 LbLcPc \\
\hline 0 & 0 & 0 & 9.38 & 8.46 & Averag & e value & 8.464 \\
\hline 0 & 0 & 0 & 9.38 & 8.46 & Expected averag & e value & 9.438 \\
\hline 0 & 0 & 0 & 8.38 & 8.46 & & $\operatorname{Var}(\mathrm{Ee})$ & 0.849 \\
\hline \multirow[t]{2}{*}{0} & 0 & 0 & 10.63 & 8.46 & $\mathrm{t}(\alpha<0.05$ & $5 ; v=3)$ & 3.1824 \\
\hline & SS & & MS & MSM/MSE= 17.5 & \multicolumn{2}{|c|}{$\mathrm{F}_{8}^{3}(\alpha=0.05)=4.066$} \\
\hline Model & 69.40 & \multicolumn{2}{|c|}{3} & 23.13 & MSMLF/MSM $=0.419$ & \multicolumn{2}{|c|}{$\mathrm{F}_{3}^{8}(\alpha=0.05)=8.845$} \\
\hline Error & 10.60 & \multicolumn{2}{|c|}{8} & 1.325 & MSE/MSEe= 1.561 & \multicolumn{2}{|c|}{$\mathrm{F}_{3}^{8}(\alpha=0.05)=8.845$} \\
\hline Exp. Error & 2.55 & \multicolumn{2}{|l|}{3} & 0.849 & MSLF/MSEe= 1.897 & \multicolumn{2}{|c|}{$\mathrm{F}_{3}^{5}(\alpha=0.05)=9.013$} \\
\hline Lack of fitting & 8.05 & \multicolumn{2}{|l|}{5} & 1.611 & \multicolumn{3}{|c|}{$r^{2}=0.868$} \\
\hline Total & 80 & \multicolumn{2}{|c|}{11} & & \multicolumn{3}{|c|}{$r^{2}$ adjusted $=0.818$} \\
\hline
\end{tabular}




\section{FIGURE CAPTIONS}

Fig. 1: Growth (percentage with respect to the initial density) of the rotifer Brachionus plicatilis in the absence $(\bullet)$ or presence (o) of several concentrations of Pediococcus acidilactici 1.02 as reported in Table 2. Continuous line: fitting to equation [3].

Fig. 2: Growth (percentage with respect to the initial density) of the rotifer Brachionus plicatilis in the absence $(\bullet)$ or presence (o) of seven strains of lactic acid bacteria as reported in Table 3. Continuous line: fitting to equation [3].

Fig. 3: Surface response (fitting to equation [5]) describing the effect of the addition of three lactic acid bacteria (Lb 3.04, Lc 1.04 e Pc 1.02) on the growth of Brachionus plicatilis. 
Figure 1

M. Planas, J.A. Vázquez, J. Marqués, R. Pérez-Lomba, M. P. González and M. Murado

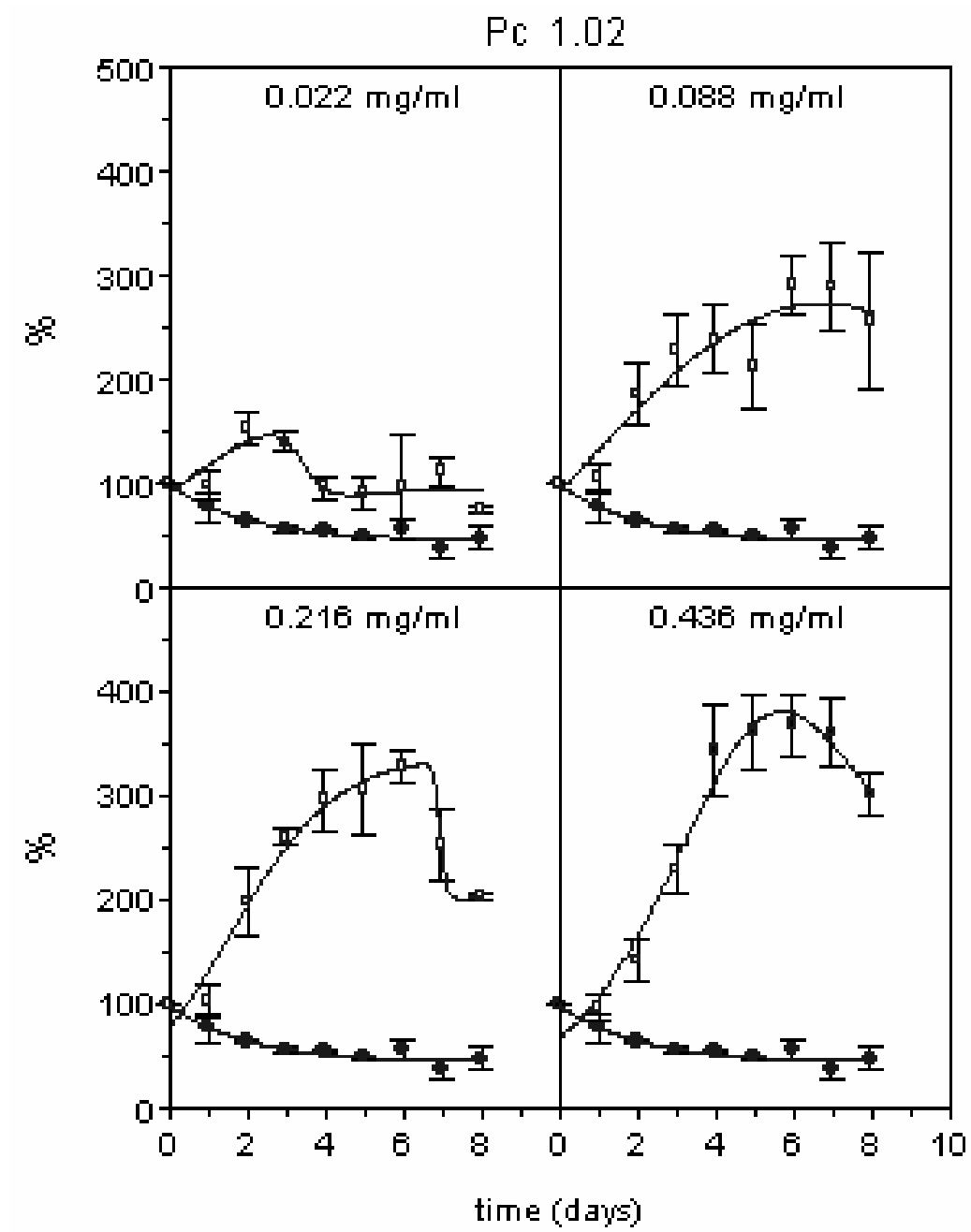


Figure 2

M. Planas, J.A. Vázquez, J. Marqués, R. Pérez-Lomba, M. P. González and M. Murado

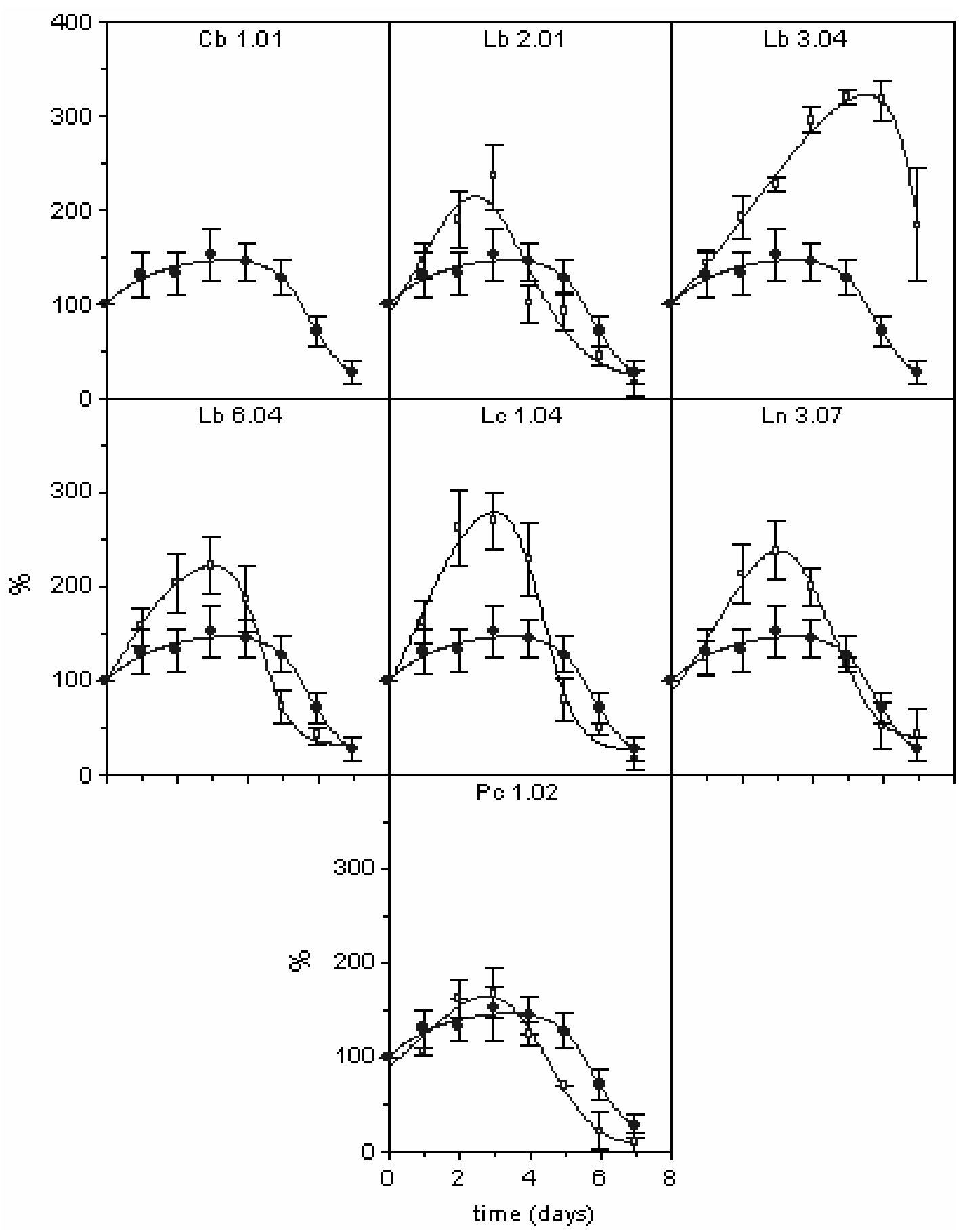




\section{Figure 3}

M. Planas, J.A. Vázquez, J. Marqués, R. Pérez-Lomba, M. P. González and M. Murado
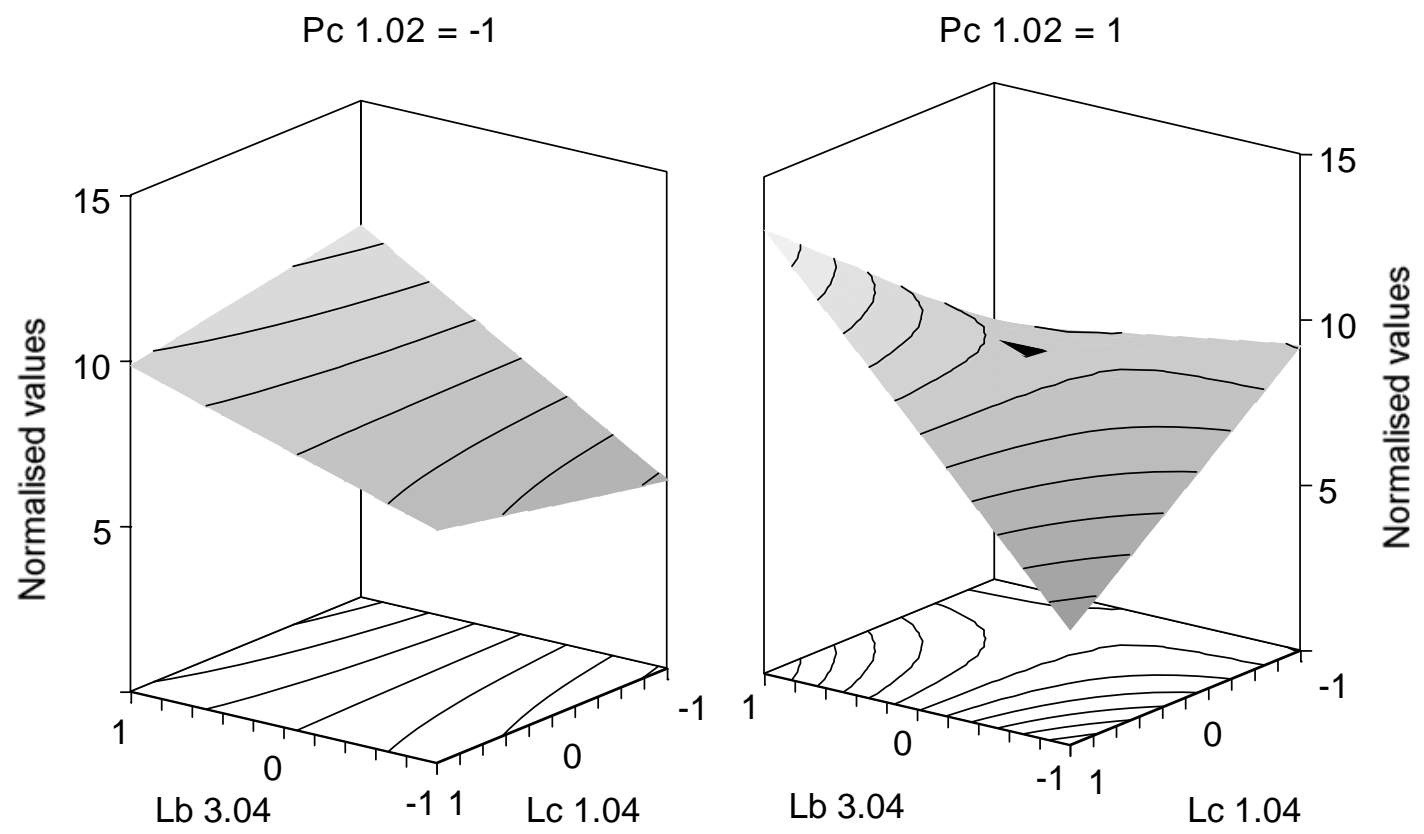
